\title{
Knowledge management in global product development: cultural and technological differences
}

\author{
R. Smeds ${ }^{1)}$, J. Amelingmeyer ${ }^{2)}$, A. Kalvelage ${ }^{2)}$, \\ M. Corso $^{3)}$, P. Olivari ${ }^{4)}$ \\ ${ }^{1)}$ Helsinki University of Technology, Department of Industrial \\ Engineering and Management \\ P.O. Box 9500, 02015 HUT, Finland \\ e-mail: riitta.smeds@hut.fi \\ ${ }^{2)}$ Darmstadt University of Technology, Fachgebiet \\ Technologiemanagement \& Marketing \\ Hochschulstr. 1, D 64289 Darmstadt, Germany, \\ e-mail: ameling@bwl.tu-darmstadt.de, \\ andre@hrz2.hrz.tu-darmstadt.de \\ 3) Politecnico di Milano, P.za Leonardo da Vinci 32, 20133 \\ Milano, Italy \\ e-mail: mariano.corso@polimi.it \\ 4) Ericsson Telecomunicazioni, Italy \\ e-mail: teipoli@tei.ericsson.se
}

\begin{abstract}
A theoretical framework for the analysis of knowledge management in global R\&D is presented, with special emphasis on the effects of national culture and the technological relatedness of the projects. The framework is applied to a comparative case study of three R\&D units of a multinational telecommunication company, situated in Finland, Italy and Germany. The results show, that national culture of the units and of the center have an effect on knowledge management practices in $R \& D$, and that the technological relatedness of the projects acts as an intervening variable. The results need to be further tested in empirical research.
\end{abstract}

Keywords

Knowledge management, global R\&D, culture, technological relatedness 


\section{INTRODUCTION}

This paper is a synthesis of two studies on learning processes in global R\&D, conducted in close international cooperation. The first research concentrated on the cultural differences in knowledge transfer (Olivari et al. 1998, Smeds et al. 1999), the second study looked also at the technological relatedness of projects (Amelingmeyer and Kalvelage 1999). In this paper, the central findings are brought together, and conclusions are drawn for knowledge management in global R\&D processes.

\section{THEORETICAL FRAMEWORK}

\subsection{Cultural differences in R\&D knowledge management}

Learning in R\&D basically means that the relevant tacit knowledge gained in one project has to be articulated and transferred to the next project, where it has to be put into use and internalized into tacit knowledge again (e.g. Nonaka and Takeuchi 1995, Hedlund 1994). The R\&D project teams act like communities of practice, creating their own knowledge during the project (Wenger 1996). But the transfer of this R\&D knowledge to global product development requires a systematic management of this learning process, i.e. knowledge management.

Managerial practices differ according to national culture, and we also assume this to hold for knowledge management in R\&D. The important cultural dimensions in the context of management are power distance and uncertainty avoidance (Smeds 1997; based on Hofstede, 1991).

Power distance describes the accepted degree of inequality between people. In small power distance countries, interaction and consultation between subordinates and bosses is preferred, equality and participation are valued. In cultures with large power distance, subordinates are unlikely to approach and contradict their bosses directly; the dominant management culture is autocratic and paternalistic (Hofstede 1991, pp. 26-28). Thus, we hypothesize that small power distance cultures also in their knowledge management favor participation and empowerment, whereas large power distance cultures more likely use hierarchical authority structures.

The uncertainty avoidance dimension measures the degree to which unstructured situations, risk and deviant ideas can be coped with in the culture. Strongly uncertainty avoiding countries tend to rely on rules, norms, and formal planning to reduce uncertainty, whereas countries characterized by weak uncertainty avoidance can tolerate uncertainty and live with it (Hofstede 1991, pp. 120-123). We hypothesize, that knowledge management practices in strongly uncertainty avoiding countries are more formal, whereas management in less uncertainty avoiding cultures allows more autonomy. (Smeds, 1997) 


\subsection{Cultural differences in $R \& D$ communication}

Inter project learning requires inter project communication. Applying Lewis' (1995) classification of communication styles to the R\&D context, we formulate the following hypotheses for knowledge transfer in different cultures:

- Linear active people plan, schedule, organize, and pursue unidirectional action chains, do one thing at a time. The German, Swiss, North American and Swedish cultures are examples of linear active cultures. In communication, linear active cultures prefer knowledge in codified form: knowledge that is highly structured and 'materialized', and transferred through artifacts like data bases, reports, organizational and technical systems.

- Multi active people are lively and loquacious. They do many things at once, prioritizing not according to a time schedule, but according to the relative thrill or importance of each appointment. E.g. Italians, Spaniards and Latin Americans belong to this group. In communication, multi active people prefer explicit knowledge, which is transferred by people, typically in meetings.

- People in reactive cultures prioritize courtesy and respect, listening quietly and calmly, and reacting carefully to the other side's proposals. Chinese, Japanese and Finns belong to the reactive cultures. They are also called listening cultures, where dialogue is a sequence of monologues, and silence is an important element in communication. Reactive cultures prefer individual faceto-face communication and sharing of experiences, where knowledge can be unstructured and the tacit component is important. But also codified knowledge is important for reactive communicators.

Based on these communication styles, we distinguish three different routes of knowledge transfer between projects (Figure 1).

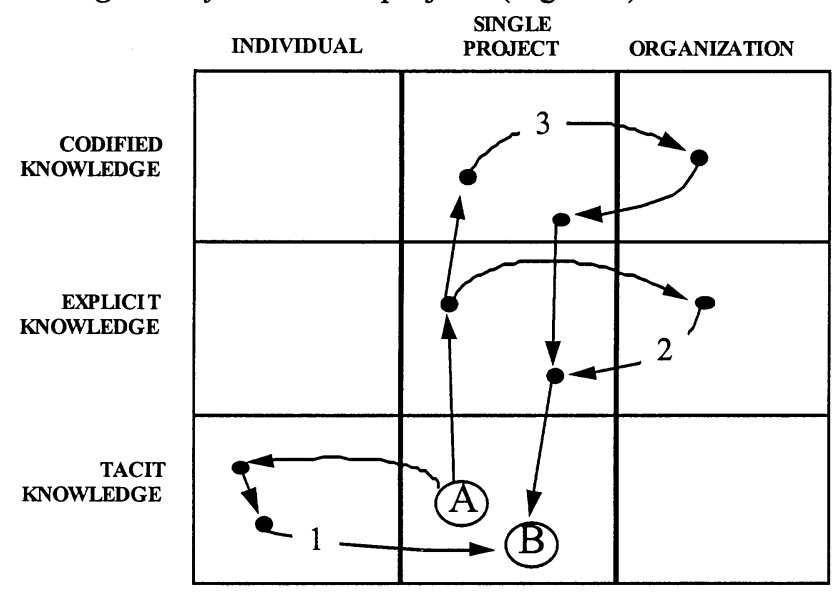

Figure 1: Routes of knowledge in inter project learning (Olivari et al. 1998)

Route 1 is based on direct tacit knowledge transfer between project A and B individuals. On route 2, tacit knowledge is transformed into explicit, which enables 
its transfer from A to B through the organizational (inter project) domain. On the longest route 3 , project knowledge is transformed to codified form, and transferred via the organizational domain to the next project.

\subsection{Technological relatedness of $R \& D$ projects}

In addition to national culture, another important contingency for learning and knowledge management in R\&D is the substance to be learnt from one project to the next. Wheelwright and Clark (1992, pp. 92-96) present a typology of R\&D projects based on the degree of change that they introduce to product and process:

- in derivative projects, the product and its production process are developed within the same product family in incremental steps,

- in platform projects, both product and process are developed to create a new 'system solution' for customers. This platform provides a basis for a new family of products.

- in radical breakthrough projects, a totally new core product and core process are developed, which build up a new product category or business.

- Research and advanced technology development projects are technological, pre-competitive explorations and investigations conducted before the commercially directed development projects.

We hypothesize, that experience from one project to the next is easily transferable in tacit form if the projects are closely related. This means a high share of tacit knowledge transfer vehicles. With the widening of the technological gap, the tacit share decreases, as does the total amount of transferable knowledge.

\section{THE CASE STUDY}

\subsection{Background}

In our empirical study, we compared the knowledge transfer mechanisms between $R \& D$ projects in three local $R \& D$ units of the telecommunication company Ericsson. Ericsson has about 100000 employees in 130 countries. The analyzed units are LMF in Finland, TEI in Italy and EED in Germany. They all participate in global R\&D projects, and are coordinated by the R\&D center in Sweden. In each unit, case studies about knowledge transfer between selected project pairs were conducted in 1998, first as a Finnish-Italian study and later repeated and enlarged in the German context. The three countries differ very much in their national culture, and the researched projects differed also in their technological relatedness (Table 1). Also the Swedish R\&D center is included in the table, to describe the global knowledge management culture. 


\section{Knowledge Management in Global Product Development}

\begin{tabular}{|c|c|c|c|c|}
\hline \multirow{2}{*}{$\begin{array}{l}\text { Country } \\
\text { and } \\
\text { researched } \\
\text { R\&D unit }\end{array}$} & \multicolumn{3}{|c|}{ National culture } & \multirow{2}{*}{$\begin{array}{l}\text { Technological } \\
\text { relatedness } \\
\text { of } R \& D \\
\text { projects }\end{array}$} \\
\hline & $\begin{array}{l}\text { Communication } \\
\text { style }\end{array}$ & $\begin{array}{l}\text { Power } \\
\text { distance }\end{array}$ & $\begin{array}{l}\text { Uncertainty } \\
\text { avoidance }\end{array}$ & \\
\hline $\begin{array}{l}\text { Finland } \\
\text { LMF }\end{array}$ & reactive & low & low & related \\
\hline $\begin{array}{l}\text { Germany } \\
\text { EED-N }\end{array}$ & linear active & medium & medium & $\begin{array}{l}\text { related \& } \\
\text { unrelated }\end{array}$ \\
\hline $\begin{array}{l}\text { Italy } \\
\text { TEI }\end{array}$ & multi active & high & high & unrelated \\
\hline $\begin{array}{l}\text { Sweden } \\
\text { R\&D center }\end{array}$ & linear active & low & low & - \\
\hline
\end{tabular}

Table 1: Country, unit, national culture and projects in the comparative cases

\subsection{Research design and methods}

To be able to research the effects of national culture on learning and knowledge management in $\mathrm{R} \& \mathrm{D}$, we tried to fulfill the ceteris paribus condition concerning other levels of culture. Since the three case units belong to the same multinational corporation, their corporate and the industrial cultures do not differ. All projects concerned hardware development for global telecommunication products. Our informants were male hardware designers, with a similar educational background, profession, age and seniority in their units.

We selected pairs of projects for comparative research: first one pair of projects at both LMF and at TEI, later three projects in EED. We tracked the knowledge transfer routes between projects, paying attention to the form and vehicles of knowledge. The technological relatedness of the projects varied, but this variation was only designed in advance for the German study; thus a full comparison between related and unrelated projects in all cultures was not possible.

The Finnish projects LMF A and LMF B were closely related projects within the same product family. The Italian project TEI A developed a derivative product, but TEI B was a breakthrough project, which developed a prototype for a totally new product category. The German EED A was a large platform project, and EED B was its derivative. EED C was a huge global breakthrough project.

The data was collected in all three cases through documents, observation, thematic personal interviews, group interviews and semi-structured questionnaires. The Finnish and Italian studies were carefully documented, so that the German study could replicate and complement them.

The interviews concentrated on the knowledge transfer between projects. The managers were asked about the general picture of 'de iure' knowledge transfer vehicles available in the units. The group interviews with the hardware designers gave us the 'de facto' knowledge transfer mechanisms. The designers also gave their preference ranking of all vehicles. 


\section{RESULTS}

The results of the comparative case studies are summarized in Table 2, as shares of the used and preferred knowledge transfer vehicles. The discussion of the results follows in the next subchapters.

\begin{tabular}{|c|c|c|c|c|c|c|c|c|}
\hline \multirow[b]{2}{*}{$\begin{array}{l}\text { Vehicles of } \\
\text { knowledge } \\
\text { transfer }\end{array}$} & \multicolumn{2}{|c|}{$\begin{array}{c}\text { LMF A, B } \\
\text { related }\end{array}$} & \multicolumn{2}{|c|}{$\begin{array}{c}\text { TEI A, B } \\
\text { unrelated }\end{array}$} & \multicolumn{2}{|c|}{$\begin{array}{c}\text { EED A, B } \\
\text { related }\end{array}$} & \multicolumn{2}{|c|}{$\begin{array}{c}\text { EED A/B, C } \\
\text { unrelated }\end{array}$} \\
\hline & $\begin{array}{l}\text { used } \\
\text { de } \\
\text { facto }\end{array}$ & $\begin{array}{l}\text { prefer- } \\
\text { red }\end{array}$ & $\begin{array}{l}\text { used } \\
\text { de } \\
\text { facto }\end{array}$ & $\begin{array}{l}\text { prefer- } \\
\text { red }\end{array}$ & $\begin{array}{l}\text { used } \\
\text { de } \\
\text { facto }\end{array}$ & $\begin{array}{l}\text { prefer- } \\
\text { red }\end{array}$ & $\begin{array}{l}\text { used } \\
\text { de } \\
\text { facto }\end{array}$ & $\begin{array}{l}\text { prefer- } \\
\text { red }\end{array}$ \\
\hline $\begin{array}{l}\text { Route 1: } \\
\text { High tacit } \\
\text { component }\end{array}$ & $\begin{array}{l}9 \\
31 \%\end{array}$ & $\begin{array}{l}4 \\
50 \%\end{array}$ & $\begin{array}{l}9 \\
25 \%\end{array}$ & $\begin{array}{l}3 \\
19 \%\end{array}$ & $\begin{array}{l}9 \\
33 \%\end{array}$ & $\begin{array}{l}8 \\
44,5 \%\end{array}$ & $\begin{array}{l}7 \\
28 \%\end{array}$ & $\begin{array}{l}6 \\
37,5 \%\end{array}$ \\
\hline $\begin{array}{l}\text { Route 2: } \\
\text { High explicit } \\
\text { component }\end{array}$ & $\begin{array}{l}5 \\
17 \%\end{array}$ & $\begin{array}{l}0 \\
0 \%\end{array}$ & $\begin{array}{l}9 \\
25 \%\end{array}$ & $\begin{array}{l}7 \\
44 \%\end{array}$ & $\begin{array}{l}5 \\
19 \%\end{array}$ & $\begin{array}{l}2 \\
11 \%\end{array}$ & $\begin{array}{l}5 \\
20 \%\end{array}$ & $\begin{array}{l}2 \\
12,5 \%\end{array}$ \\
\hline $\begin{array}{l}\text { Route 3: } \\
\text { High codified } \\
\text { component }\end{array}$ & $\begin{array}{l}15 \\
52 \%\end{array}$ & $\begin{array}{l}4 \\
50 \%\end{array}$ & $\begin{array}{l}18 \\
50 \%\end{array}$ & $\begin{array}{l}6 \\
37 \%\end{array}$ & $\begin{array}{l}13 \\
48 \%\end{array}$ & $\begin{array}{l}8 \\
44,5 \%\end{array}$ & $\begin{array}{l}13 \\
52 \%\end{array}$ & $\begin{array}{l}8 \\
50 \%\end{array}$ \\
\hline Sum of vehicles & $\begin{array}{l}29 \\
100 \%\end{array}$ & $\begin{array}{l}8 \\
100 \%\end{array}$ & $\begin{array}{l}36 \\
100 \%\end{array}$ & $\begin{array}{l}16 \\
100 \%\end{array}$ & $\begin{array}{l}27 \\
100 \%\end{array}$ & $\begin{array}{l}18 \\
100 \%\end{array}$ & $\begin{array}{l}25 \\
100 \%\end{array}$ & $\begin{array}{l}16 \\
100 \%\end{array}$ \\
\hline Vehicles de iure & \multicolumn{2}{|l|}{36} & \multicolumn{2}{|l|}{34} & \multicolumn{2}{|l|}{34} & \multicolumn{2}{|l|}{34} \\
\hline $\begin{array}{l}\text { Locally added } \\
\text { vehicles }\end{array}$ & \multicolumn{2}{|l|}{3} & \multicolumn{2}{|l|}{7} & \multicolumn{2}{|l|}{2} & \multicolumn{2}{|l|}{0} \\
\hline Vehicles not used & \multicolumn{2}{|l|}{10} & \multicolumn{2}{|l|}{5} & \multicolumn{2}{|l|}{7} & \multicolumn{2}{|l|}{7} \\
\hline
\end{tabular}

Table 2 Knowledge transfer vehicles between related and unrelated projects at LMF, TEI and EED, according to the form of knowledge transferred

\subsection{Knowledge management and culture}

Finland. The preferences of the designers at LMF were evenly divided into vehicles for tacit knowledge transfer (route 1) and into vehicles for codified knowledge transfer (route 3). None of the vehicles for explicit knowledge transfer in meetings (route 2) was among the preferred ones. The pattern supports the reactive communication culture, and also the small power distance, medium uncertainty avoiding knowledge management practice of the Finnish culture: strong individual communication with no reliance on hierarchy in meetings, and quite high preference towards codified knowledge for uncertainty avoidance.

Italy. At TEI, the preferences of the designers were the opposite: the most favored vehicles were the explicit knowledge transfer vehicles for route 2 (typically 
meetings). The vehicles for codified knowledge transfer on route 3 came second, and the vehicles for tacit knowledge transfer on route 1 were the least preferred. This pattern is representative of a multi active communication culture. It is also in accordance with the large power distance, high uncertainty avoiding management culture. The meetings give the authority structure for human communication, and strong uncertainty avoidance is reflected in the highest total amount of codified knowledge transfer vehicles de facto used in R\&D. However, only six out of eighteen de facto vehicles for codified knowledge transfer were preferred by the Italian designers. The strong uncertainty avoidance might here be blurred by the multi active communication style, which is less keen on codified data in practice.

Germany. At EED, the most preferred vehicles of knowledge transfer between the projects were the structured mechanisms for codified knowledge. Also tacit knowledge transfer was frequently preferred, but the individual face-to-face discussions with the colleagues were typically only initiated after a thorough search for codified knowledge. Of the explicit knowledge transfer vehicles, only two formal meetings were favored. The heavy reliance on codified data gives support to our hypotheses about inter project learning in a linear active communication culture. The reliance on formal communication is also in accordance with medium uncertainty avoidance and power distance.

The Swedish Ericsson R\&D center has introduced many global systems for codified knowledge transfer to its local units, which reflects well the Swedish linear active communication style. Most of these systems were de facto used, and 'taken-for-granted' in the three units. However, only the global project management model was preferred in all three units. The differences in the portfolios of preferred knowledge vehicles demonstrate local autonomy in inter project learning mechanisms, which mirrors the weak uncertainty avoidance of the center. The low power distance is supportive of the local, bottom up introduction of new knowledge transfer vehicles, and their application also into global use. The future challenge of Ericsson's global knowledge management is the cultivation of this diversity into locally leveraged innovations in learning mechanisms, and the guidance of this innovation process with a global knowledge management strategy.

\subsection{Technological relatedness as an intervening variable}

From the two project comparisons at the German EED, some conclusions concerning the impact of technological relatedness on inter project learning can be drawn. Between the related projects $\mathrm{A}$ and $\mathrm{B}$, and the unrelated project $\mathrm{C}$ there was no difference in the preference towards explicit and codified knowledge transfer: all three projects favored the same vehicles for explicit and codified knowledge. But in the knowledge transfer from project A to its closely related derivative B, two more vehicles of knowledge with a high tacit component were developed.

The closely related Finnish projects LMF A and LMF B, and the equally close German project pair EED A and EED B, differ only slightly in their relative shares of preferred vehicle types, and in the direction hypothesized by communication culture. The main difference between them lies in the total amount of preferred 
vehicles: with the same technological relatedness, EDD prefers a much larger portfolio (18) than LMF (8). This supports our hypothesis of a more formal and less empowering approach to knowledge management in the German relative to the Finnish culture.

A similar comparison between the two unrelated project pairs, TEI A and TEI B, and EED A/B and EED C, supports the cultural communication differences. The total amount of knowledge transfer vehicles used 'de facto' in the unrelated pairs of projects was 36 in TEI and only 25 in EED, which is an indication of high uncertainty avoidance in knowledge management in the Italian TEI. However, the amount of preferred vehicles was exactly the same in both cases; the German unit seems to accept the rules more gladly. Out of the three cultures, the Italian culture is strongest in uncertainty avoiding, but it might, through its multi active communication style, be more reluctant to apply the rules in practice than the medium uncertainty avoiding, but linear active German culture.

TEI added the highest number of own knowledge transfer vehicles to the portfolio (Table 2). This can be a consequence of the breakthrough project's totally new knowledge needs, or of the multi activity of the Italian culture. - The German EED did not invent any new knowledge transfer mechanism, although it too managed a breakthrough project EED C.

In the comparison of the unrelated TEI projects and the related LMF projects, the higher share of tacit knowledge transfer at LMF can partly be caused by the technological closeness of the LMF projects, and only partly by the Finnish reactive, small power distance culture.

5 Conclusions

The results show, that the national culture of the local R\&D units and of the global center have an important impact on knowledge transfer and management practices in global R\&D. The technological relatedness of the projects acts however as an intervening variable. According to the results in the German case, it seems that technological closeness increases the share of vehicles for tacit knowledge transfer. The observations in the Italian case indicate, that a wide technological gap would increase the local innovation of new knowledge transfer mechanisms. However, the German case does not confirm this finding.

The design of the empirical study did not allow full comparisons between technologically related and unrelated projects. Thus the effects of technological relatedness especially on explicit and codified knowledge transfer could not be explored. More empirical case studies with carefully controlled contingencies are needed to research knowledge management in global R\&D further.

\section{REFERENCES}

Amelingmeyer, J. and Kalvelage, A. (1999) Inter-project Learning in New Product Development, accepted for the $6^{\text {th }}$ International Product Development Management Conference, Cambridge, July 5/6, 1999. 
Hedlund, G. (1994) A model of knowledge and the N-form corporation, Strategic Management Journal, 1994, Vol. 15, pp. 73-90.

Hofstede, G. (1991) Cultures and Organizations. Software of the mind. McGrawHill, NY, 1991.

Lewis, R. D. (1995) When cultures collide. Managing successfully across cultures. Nicholas Brealey Publishing Limited, London, 1996.

Nonaka, I. and Takeuchi, H., (1995), The Knowledge Creating Company. Oxford University Press, New York.

Olivari, P., Smeds, R. and Corso, M. (1998) Continuous Learning in Product Development: A Cross-cultural Comparison between Finland and Italy. In: Harry Boer and Jose Gieskes (eds.) Proceedings of the Second EuroCINet Conference "Continuous Improvement: From Idea to Reality", Twente University Press, 302-313.

Smeds, R, Olivari, P. And Corso, M (1999): Continuous Learning in Global Product Development: A Cross-Cultural Comparison. Submitted for publication in International Journal of Technology Management. (in print)

Smeds, R. (1997) Radical change through incremental innovation: generic principles and cultural differences in evolution management, International Journal of Technology Management, Vol. 14, No. 1, 146-162.

Wheelwright, S. C. and Clark, K. B. (1992) Revolutionizing Product Development. Quantum Leaps in Speed, Efficiency and Quality. The Free Press, New York.

\section{BIOGRAHPY}

D.Sc. Riitta Smeds is Docent at Helsinki University of Technology. Her research areas are enterprise evolution, management of technology and innovation, organizational learning, business process re-engineering, and enterprise simulation. M.Sc. Jenny Amelingmeyer is Research Assistant at the Darmstadt University of Technology. Her research interests are R\&D management, business-to-business marketing and especially knowledge management.

M.Sc. André Kalvelage's thesis at Darmstadt University of Technology dealt with inter-project learning in new product development in the German Ericsson unit.

$\mathrm{Ph}$.D. Mariano Corso is Associate Professor of Management Engineering. His research interests focus on innovation management and organization.

M.Sc. Paola Olivari is Quality Manager in the Ericsson R\&D center Milan. In her thesis at Politecnico di Milano she investigated inter-project learning in new product development at Ericsson in Finland and Italy. 